\title{
Lumen
}

Selected Proceedings from the Canadian Society for Eighteenth-Century Studies

\section{Reversal, Repression, and Revenge in The Monk}

\section{L. MacDonald}

Volume 12, 1993

URI : https://id.erudit.org/iderudit/1012587ar

DOI : https://doi.org/10.7202/1012587ar

Aller au sommaire du numéro

Éditeur(s)

Canadian Society for Eighteenth-Century Studies / Société canadienne d'étude du dix-huitième siècle

ISSN

1209-3696 (imprimé)

1927-8284 (numérique)

Découvrir la revue

Citer cet article

MacDonald, D. L. (1993). Reversal, Repression, and Revenge in The Monk.

Lumen, 12, 149-155. https://doi.org/10.7202/1012587ar

Copyright (c) Canadian Society for Eighteenth-Century Studies / Sociéte canadienne d'étude du dix-huitième siècle, 1993
Ce document est protégé par la loi sur le droit d'auteur. L'utilisation des services d'Érudit (y compris la reproduction) est assujettie à sa politique d'utilisation que vous pouvez consulter en ligne.

https://apropos.erudit.org/fr/usagers/politique-dutilisation/ 


\section{Reversal, Repression, and Revenge in The Monk}

M.G. Lewis's sexuality has often been alluded to but never properly discussed. Some understanding of it, however, is helpful towards an understanding of the rich sexual pathology of his most famous work, The Monk - not, I believe, because Lewis's own sexuality was particularly pathological, but because it gave him a particularly vivid sense of the sexual pathology of his society.

The evidence in Lewis's letters is abundant enough to be cumulatively suggestive, even if it would not be quite conclusive in a court of law. Not surprizingly, most of it is oblique, and it becomes more oblique as Lewis grows older. What it suggests is that he was strongly attracted to men, but that he thought of these attachments as (in Louis Crompton's terms) romantic friendships rather than love affairs (72-76), or (in Eve Kosofsky Sedgwick's terms) as homosocial rather than homosexual. Otherwise, of course, he would hardly have mentioned them at all.

His increasing discretion parallelled an increasing persecution of homosexuals. From about 1780 on, prosecutions for sodomy became more and more frequent (Trumbach, 'Sodomitical Subcultures' 113). They also became more and more successful in obtaining the full penalty called for by the law. In London and Middlesex, in the last half of the eighteenth century, about one man in a decade was hanged for sodomy; in the early years of the nineteenth, the average rose to about one a year (Harvey 939).

Popular violence kept pace with this judicial violence. For the lesser offense of attempted sodomy, the sentence commonly included exposure in the pillory (Trumbach, 'London's Sodomites' 21); as Edmund Burke warned, the crowd often converted this into a death sentenceand one, moreover, which was 'as much more severe than execution at Tyburn, as to die in torment, was more dreadful than momentary death.' Burke was commenting on the case of William Smith, a coachman, who was exposed along with his partner in crime in April 1780. One newspaper reported: 'A vast Concourse of People had assembled upon the Occasion, many by Seven o'Clock in the Morning, who had collected dead Dogs, Cats, \&c. in great Abundance, which were plentifully thrown 
at them; but some Person threw a Stone, and hit the Coachman on the Forehead, and he immediately dropped on his Knees, and was to all Appearance dead' (Crompton 31-32).

By the time Lewis reached maturity, the mob no longer seemed content to kill its victims. It seemed to insist on disfiguring them, as if to ensure that no-one guilty of such an offense could be recognized as human. Joshua Viguers was exposed on 25 September 1810 and pelted so severely that 'The head of this wretch when he reached Newgate, was compared to a swallow's nest. It took three buckets of hot water to restore it to any thing like a human shape' (Crompton 163). The most famous such incident occurred two days later. Six men arrested at the White Swan tavern in Vere Street were taken from Newgate to a pillory in the Haymarket. The crowd was waiting, armed with offal, excrement, rotten vegetables, fruit, and fish, and dead dogs and cats. Before the caravan had proceeded very far,

the prisoners resembled bears dipped in a stagnant pool. ... Before the cart reached Temple-bar, the wretches were so thickly covered with filth, that a vestige of the human figure was scarcely discernible.

Before any of them reached the place of punishment, their faces were completely disfigured by blows and mud; and before they mounted, their whole persons appeared one heap of filth. (Crompton 165-66)

The reporter is quite explicit about, and fully in sympathy with, the dehumanizing intentions of the crowd.

Of course, if Lewis was 'only' homosocial rather than openly homosexual, he was not directly threatened by this kind of violence. But quite apart from the possibility that it was precisely such a threat that made open homosexuality unthinkable for him, the power of the threat is not limited to homosexuals. As Kosofsky Sedgwick has argued, the very irrationality of the threat makes it impossible for any man-especially a man with pronounced homosocial feelings - to be sure that he is safe from it (88-89). The Monk is Lewis's response to it.

In the main plot of The Monk, the homosexual and homosocial themes are focussed on the figure first introduced as Rosario, a young novice and the protégé of Ambrosio, the monk of the title. Rosario is soon revealed to be Matilda, a woman who has entered the convent in disguise out of love for Ambrosio; at the end of the novel, she is unmasked again, as a demon who has entered the convent in order to tempt him. Transsexuality is a conventional characteristic of demons (Grudin 140-41). In a long discussion of whether demons can beget 
children, the Malleus Maleficarum concedes that they cannot do so directly, since they do not have living bodies, but argues that they can do so indirectly, 'by obtaining human semen' as succubi and then 'themselves transferring it' as incubi (Krämer 22): 'For the devil is Succubus to a man, and becomes Incubus to a woman' (26).

Until the end of the novel, however, Matilda is not identified as a transsexual demon but as a transvestite human being with supernatural powers. In this role, her cross-dressing is also conventional. In many cultures, those who cross the boundary between the natural and the supernatural also cross the boundary between the genders. In the culture of Catholic Europe, Joan of Arc and her judges both saw her cross-dressing as a sign of her special relationship with the supernatural world: Joan thought it had been commanded by God; the judges thought it meant she was a witch (Dekker 43).

Lewis's devil is, however, unconventional in appearing to the same victim in both male and female roles. It is also unconventional in its performance of those roles. As Rosario, it is stereotypically feminine: the narrative stresses Rosario's air of 'mystery,' his 'profound melancholy,' his 'fearful[ness],' his 'sweetness,' his 'docility' (66-67), his 'exquisite sensibility' (78), his 'gentle[ness]' and 'submissive[ness]' (234). As Matilda, the demon 'assumed a sort of courage and manliness in her manners and discourse'; Ambrosio 'grieved that Matilda preferred the virtues of his sex to those of her own' (233-34). Her increasing masculinity disgusts him; at the same time, 'as her passion grew ardent, Ambrosio's grew cold; the very marks of her fondness excited his disgust, and its excess served to extinguish the flame which already burned but feebly in his bosom' (237). The two sources of Ambrosio's disgust are closely related, since Lewis's culture thought of sexually aggressive women not just as masculine but almost as physically hermaphroditic: Byron referred to the Countess of Westmorland as 'the Sapphic Westmoreland' because of her interest in young men, not in women; her clitoris, he remarked, 'is supposed to be of the longest' (5: 215).

Ambrosio undergoes the opposite transformation. As a virgin, he is not only emphatically masculine but oppressively phallic, 'the sole uncorrupted pillar of the church' (65). The first description of him mentions his 'noble port' - that is, his erect posture-his 'lofty' stature, his aquiline nose, his 'penetrating' eye and voice (45). Once he has been seduced by Matilda, he takes on such stereotypically feminine traits as hypocrisy $(229,262)$, curiosity (234; cf. 329), and timidity; Matilda comments on the change in him: 'That mind which I esteemed so great and valiant, proves to be feeble, puerile, and grovelling, a slave to vulgar errors, and weaker than a woman's' (266). In making a man of him, she has unmanned him. 
In the seventeenth century, heterosexual debauchery as well as sodomy was believed to make a man effeminate (Bray 130-31 n. 77). By Lewis's time, this belief had largely dissipated, as the general stereotype of the libertine had been divided into specific heterosexual and homosexual versions (Trumbach, 'Sodomitical Subcultures' 117-18). In reverting to the older belief, Lewis undercuts the new stereotype of the molly.

Matilda leads Ambrosio around a circle of vices. He begins with the idolatrous worship of a picture of the Virgin; since his idolatry is charged with eroticism, and the Virgin is the Mother of God, his worship has overtones of incest, which are almost explicit in his meditations in front of the picture:

What beauty in that countenance! ... how graceful is the turn of that head! what sweetness, yet what majesty in her divine eyes! how softly her cheek reclines upon her hand! Can the rose vie with the blush of that cheek? can the lily rival the whiteness of that hand? Oh! if such a creature existed, and existed but for me! were I permitted to twine round my fingers those golden ringlets, and press with my lips the treasures of that snowy bosom! (65)

Matilda is able to seduce Ambrosio largely because of her resemblance to the picture; she is careful to show him her face, her ringlets, and (while threatening to stab herself) her snowy bosom.

Ambrosio's idolatry has overtones not only of incest but also, perhaps, of homosexuality. (In an unpublished letter to Lord Holland, Lewis referred to one of his own romantic attachments as 'the God of my idolatry.') The notorious verse in Leviticus that decreed the death penalty for sodomy (20:13) did so because ritual sodomy was part of the idolatrous cult of the Canaanites (Leviticus 20: 23; Westermarck 2: 487-88). Idolatry is associated with sodomy throughout the Old Testament; in the New, Paul interpreted the sodomy of the Gentiles as a divine punishment for their idolatry (Romans 1: 23-7; Westermarck 2: 488-89). Protestant England associated Catholic idolatry with sodomy (Crompton 60-61; Trumbach, 'London's Sodomites' 11). In 'The Stage Defended' (1726), John Dennis remarked of Italy: 'of all the Countries of the Christian World, that Country has been, is, and is like to be, the most famous for this execrable Vice, in which Idolatry has set up its Head Quarters' (2: 315). The transformations of Ambrosio and RosarioMatilda take place in a context which Lewis's readers would have seen not just as generally deplorable but as specifically perverse; Lewis 
makes it clear that Ambrosio's monastic education has prepared him well for his feminization by Matilda (237-38).

Ambrosio's friendship with Rosario has strongly homosocial overtones, and it begins the feminization that his seduction completes:

with [Rosario] alone did [Ambrosio] lay aside his habitual severity. When he spoke to him, he insensibly assumed a tone milder than was usual to him; and no voice sounded so sweet to him as did Rosario's. ... Ambrosio was every day more charmed with the vivacity of his genius, the simplicity of his manners, and the rectitude of his heart: in short, he loved him with all the affection of a father. He could not help sometimes indulging a desire secretly to see the face of his pupil.... (67)

Since Ambrosio loves Rosario like a father, their romantic friendship inherits some of the incestuous overtones of his idolatry. And since, according to the conventional morality to which the novel pays lipservice, both incest and homosexuality are narcissistic forms of sexuality, the transition from one to the other is smooth. Ambrosio's affair with Matilda has explicitly homosexual overtones, despite her gender, because of her masculine character. Finally, the rape of his sister Antonia brings him back not only to incest but also to idolatry, since Antonia is emphatically a virgin - we are told repeatedly that she does not even know the difference between men and women $(44,261$, 262) - and she is given to uttering such mild oaths as 'Holy virgin!' (251).

The subplot deals with the themes of male homophobia and paranoia, of repressed desire and persecution, which Kosofsky Sedgwick considers characteristic of the Gothic, but it disguises them-so thoroughly that she concludes they do not occur in novels by homosexual authors like Lewis (92). It carries out, on the level of plotting, something analogous to what the main plot presents, on the level of character, in the transformations of Ambrosio and Matilda.

The nuns of the convent of St. Clare persecute Agnes de Medina as relentlessly as Gil-Martin persecutes Wringhim in Hogg's Private Memoirs and Confessions of a Justified Sinner (1824). The official reason for their persecution is her indulgence in forbidden love, but it is a heterosexual love, for Don Raymond de las Cisternas. The real reason for the persecution is the Prioress's unacknowledged love for Ambrosio (72, $232,394)$. This love, of course, is also heterosexual, though it also has homosexual overtones, since the Prioress is even more masculine in character than Matilda. In short, the subplot presents male homophobia 
in double drag, as female heterophobia. The two plots add up to a reductio ad absurdum of the logic of sexual repression in Lewis's culture. Pressed hard enough, conventional conceptions of the masculine and the feminine, the heterosexual and the homosexual, the sexually active and the castrated tend to turn into each other.

The novel's subversiveness becomes blunter and more emphatic at climax of the subplot, a scene of mob violence which closely parallels the mob violence against homosexuals in Lewis's time:

The rioters heeded nothing but the gratification of their barbarous vengeance. They refused to listen to her: they shewed her every sort of insult, loaded her with mud and filth, and called her by the most opprobrious appellations... At length a flint, aimed by some well-directing hand, struck her full upon the temple. She sank upon the ground bathed in blood, and in a few minutes terminated her miserable existence. Yet though she no longer felt their insults, the rioters still exercised their impotent rage upon her lifeless body. They beat it, trod upon it, and ill-used it, till it became no more than a mass of flesh, unsightly, shapeless, and disgusting. (344)

The stone aimed at her temple recalls the death of William Smith in 1780; the dehumanizing frenzy of the mob anticipates the pelting of Joshua Viguers and the men of Vere Street in 1810. In the novel, as is usual in the Gothic, the violence is displaced in time and space, from contemporary England to the Spain of the Counter-Reformation. Another of Lewis's displacements is more unusual. The victim of his mob is not a sexual deviant but the Prioress, the agent of a repressive sexual orthodoxy. The forces of repression have been turned against themselves. (This involution of repressive violence is given another turn of the screw when the rioters set fire to the convent and many of them perish in the flames.) Hidden beneath the conventional, if distasteful, anti-Catholicism of the novel is something less conventional and more attractive: the revenge fantasy of a man whose sexuality put him at lifelong risk.

\section{D.L. MACDONALD}

University of Calgary 


\section{Works Cited}

Bray, Alan. Homosexuality in Renaissance England. London: Gay Men's P, 1982.

Byron, George Gordon Noel. Byron's Letters and Journals. Ed. Leslie A. Marchand. 12 vols. London: John Murray, 1973-82.

Crompton, Louis. Byron and Greek Love: Homophobia in 19th-Century England. Berkeley: U of California P, 1985.

Dekker, Rudolf M., and Lotte C. van de Pol. The Tradition of Female Transvestism in Early Modern Europe. New York: St. Martin's, 1989.

Dennis, John. The Critical Works of John Dennis. Ed. Edward Niles Hooker. 2 vols. Baltimore: Johns Hopkins UP, 1939-43.

Grudin, Peter. 'The Monk: Matilda and the Rhetoric of Deceit.' Journal of Narrative Technique 5 (1975): 136-46.

Harvey, A.D. 'Prosecutions for Sodomy in England at the Beginning of the Nineteenth Century.' Historical Journal 21 (1978): 939-48.

Krämer, Heinrich, and James Sprenger. The Malleus Maleficarum. 1928. Trans. and ed. Montague Summers. New York: Dover, 1971.

Lewis, Matthew Gregory. The Monk. Ed. Louis F. Peck. Introd. John Berryman. New York: Grove, 1952.

-. Letter to Lord Holland. 18 February 1805. Add. Ms. 51,641 ff. 90-1. British Library, London.

Sedgwick, Eve Kosofsky. Between Men: English Literature and Male Homosocial Desire. New York: Columbia UP, 1985.

Trumbach, Randolph. 'London's Sodomites: Homosexual Behavior and Western Culture in the 18th Century.' Journal of Social History 11 (1977-78): 1-33.

-. 'Sodomitical Subcultures, Sodomitical Roles, and the Gender Revolution of the Eighteenth Century: The Recent Historiography.' 'Tis Nature's Fault: Unauthorized Sexuality during the Enlightenment. Ed. Robert Purks Maccubbin. Cambridge: Cambridge UP, 1987. 109-21.

Westermarck, Edward. The Origin and Development of the Moral Ideas. 2 vols. 2nd ed. London: Macmillan, 1912-17. 